\title{
GAMBARAN KADAR KOLESTEROL LOW DENSITY LIPOPROTEIN DARAH PADA MAHASISWA ANGKATAN 2011 FAKULTAS KEDOKTERAN UNIVERSITAS SAM RATULANGI DENGAN INDEKS MASSA TUBUH $\geq 23 \mathrm{~kg} / \mathrm{m}^{2}$
}

\author{
${ }^{1}$ Yuyun Ardanan \\ ${ }^{2}$ Stefana H.M Kaligis \\ ${ }^{2}$ Yanti M. Mewo \\ Bagian Biokimia Fakultas Kedokteran Universitas Sam Ratulangi \\ Email: yuyunardanan@yahoo.com
}

\begin{abstract}
Description of blood low density lipoprotein cholesterol level at young age (18-20 years old) can be useful to assess the risk of disease. The purpose of this study was to find out the description of blood LDL cholesterol levels at student year 2011 Faculty of Medicine Sam Ratulangi University with BM£ $23 \mathrm{~kg} / \mathrm{m} 2$. This is a descriptive study and followed by 26 respondents. The respondents was selected using purposive sampling method. The results showed 7,7 \% respondents have high blood LDL cholestrerol level, 19,2 \% respondents have borderline high level, $50 \%$ have near optimal level and 23,1 \% have normal/optimal level. From the result can be concluded the description of blood low density lipoprotein cholesterol level at students year 2011 Faculty of Medicine Sam Ratulangi University mostly (76,9 \%) have more than normal/optimal blood LDL cholesterol level.
\end{abstract}

Keywords: LDL cholesterol level, student year 2011, BMI $\geq 23 \mathrm{~kg} / \mathrm{m}^{2}$.

\begin{abstract}
Abstrak: Penilaian gambaran kadar kolesterol low density lipoprotein darah pada usia dewasa muda (18-20 tahun) dapat bermanfaat untuk menilai tingkat resiko terjadinya gangguan. Penelitian ini bertujuan untuk mengetahui gambaran kadar kolesterol LDL darah pada mahasiswa angkatan 2011 Fakultas Kedokteran Universitas Sam Ratulangi dengan $\geq \mathrm{IM} 3 \mathbf{\mathrm { kg }} / \mathrm{m} 2$.

Penelitian ini merupakan penelitian deskriptif dan diikuti oleh 26 respoden. Pemilihan responden menggunakan cara purposive sampling. Hasil penelitian didapatkan persentase sebesar 7,7 \% reponden memiliki kadar kolesterol LDL tinggi, 19,2 \% responden memiliki kadar kolesterol LDL pada batas tinggi, 50 \% memiliki kadar kolesterol LDL yang mendekati optimal, dan 23,1 \% responden memiliki kadar kolesterol LDL normal/optimal. Dari hasil penelitian disimpulkan bahwa gambaran kadar kolesterol LDL darah mahasiswa angkatan 2011 Fakultas Kedokteran Universitas Sam Ratulangi sebagian besar (76,9 \%) memiliki kadar kolesterol LDL yang meningkat di atas normal.
\end{abstract}

Kata Kunci: Kadar kolesterol LDL, mahasiswa angkatan 2011, IMT $\geq 23$ kg/m².

Makanan yang memiliki kadar lemak tinggi serta aktifitas fisik yang kurang dapat menjadi faktor risiko terjadinya berbagai gangguan kesehatan, salah satunya adalah dislipidemia. Dislipidemia adalah kelainan metabolisme lipid atau lemak yang ditandai dengan peningkatan maupun penurunan fraksi lipid dalam plasma, dan sekitar 80\% 
disebabkan oleh faktor gaya hidup, sedangkan $20 \%$ sisanya disebabkan oleh faktor genetik. ${ }^{1}$

Prevalensi dislipidemia di seluruh dunia sangatlah tinggi, baik pada pria maupun wanita. Data penelitian di Beijing tahun 2006 menunjukkan bahwa sekitar $56 \%$ dari penduduk usia45 tahun menderita dis lipidemia. ${ }^{2}$ Pada penelitian yang dilakukan oleh Katamso dkk terhadap 656 responden yang dilakukan di empat kota besar di Indonesia (Jakarta, Bandung, Yogyakarta, dan Padang) didapatkan keadaan dislipidemia berat usia diatas 55 tahun paling banyak di kota Padang dan Jakarta sebesar $>56 \%$, diikuti dengan kota Bandung sebesar 52,2\% dan Yogyakarta sebesar 27,7\% . ${ }^{3}$

Salah satu kelompok dislipidemia menurut klasifikasi European Atheroselerosis Society (EAS) adalah hiperkolesterolemia. ${ }^{3}$ Hiperkolesterolemia berkaitan erat dengan low density lipoprotein (LDL), salah satu jenis lipoprotein yang bertugas membawa kolesterol ke bagian tubuh yang membutuhkan sehingga peningkatan kolesterol juga akan berdampak pada peningkatan LDL. ${ }^{4}$

Dampak lanjut dari peningkatan LDL adalah terjadinya penyakit jantung koroner. Penyakit jantung koroner terjadi akibat kadar kolesterol LDL teroksidasi yang berlebihan yang akan membentuk plak aterosklerosis pada pembuluh darah koroner jantung, pembuluh darah tersebut menjadi sempit dan mengakibatkan otot jantung tidak dapat menerima aliran darah yang cukup. ${ }^{5}$

Kecenderungan untuk mengonsumsi makanan yang tinggi lemak dan karbohidrat juga akan berpengaruh pada peningkatan berat badan secara berlebih atau obesitas. Hal ini disebabkan karena adanya penimbunan lemak yang akan disimpan dijaringan adiposa. Sejumlah kelainan metabolisme seringkali dihubungkan dengan obesitas sebagai komponen sindrom metabolik, salah satunya adalah dislipidemia. ${ }^{6}$ Hasil Riset Kesehatan Dasar (Riskesdas) Indonesia tahun 2010 menunjukkan angka kelebihan berat badan dan obesitas pada penduduk dewasa di atas usia 18 tahun besarnya 21,7\%. ${ }^{7}$ Sulawesi Utara merupakan salah satu dari 12 propinsi yang mempunyai prevalensi obesitas umum yang tinggi pada umur $\geq 15$ tahun. $^{8}$

Low density lipoprotein merupakan lipoprotein hasil penguraian dari lipoprotein berdensitas antara atau intermediate density lipoprotein (IDL) dengan diameter 20-25 nm serta densitas 1,019-1,063 g/mL. ${ }^{9}$ Komposisi utama LDL adalah kolesterol dan ester kolesterol. Terdapat juga triasilgliserol dan fosfolipid dengan kadar yang lebih rendah. Protein pada lipoprotein dikenal sebagai apolipoprotein atau apoprotein. Satu atau lebih apolipoprotein ditemukan pada setiap lipoprotein. Apolipoprotein utama LDL adalah apolipoprotein B yang juga ditemukan pada VLDL dan kilomikron. Ada beberapa peran dari apolipoprotein, salah satunya adalah sebagai penghubung untuk interaksi dengan reseptor lipoprotein dalam jaringan. Apolipoprotein yang berperan pada LDL adalah apo B-100.

Hiperlipidemia adalah faktor risiko utama untuk aterosklerosis. Salah satunya adalah Hiperkolesterolemia. Komponen utama kolesterol serum total yang menyebabkan peningkatan risiko yaitu kolesterol low density lipoprotein (LDL). ${ }^{11}$

Secara fisiologis obesitas atau berat badan berlebih didefinisikan sebagai suatu keadaan dengan akumulasi lemak yang tidak normal atau berlebihan dijaringan adiposa (jaringan lemak), sehingga dapat mengganggu kesehatan. ${ }^{12}$

Pembesaran adiposit yang menunjukan peningkatan aktivitas lipolitik, berperan dalam peningkatan asam lemak bebas melalui sirkulasi portal menuju ke hati. Kadar asam lemak bebas portal yang tinggi akan menstimulasi sintesis triasilgliserol di hati, yang akan disekresikan dalam VLDL dan produksi apo-B yang merupakan protein utama di hati. Tingginya pembentukan VLDL tersebut dapat meningkatkan kadar kolesterol LDL yang merupakan penguraian dari VLDL. ${ }^{10,13}$ 


\section{METODE PENELITIAN}

Jenis penelitian ini adalah penelitian deskriptif. Penelitian ini dilaksanakan selama bulan Oktober 2012 sampai Januari 2013, dan bertempat di Fakultas Kedokteran Universitas Sam Ratulangi Manado.

Populasi adalah seluruh mahasiswa angkatan 2011 Fakultas Kedokteran Universitas Sam Ratulangi dengan IM $23 \mathrm{~kg} / \mathrm{m}^{2}$. Sampel penelitian dipilih berdasarkan cara pemilihan Purposive Sampling dan didapatkan 26 orang mahasiswa dengan IME 23 $\mathrm{kg} / \mathrm{m}^{2}$.

\section{HASIL PENELITIAN}

Hasil penelitian ini didapatkan persentase responden dengan kadar kolesterol LDL $<100 \mathrm{mg} / \mathrm{dL}$ yaitu sebesar 23,1 \%, kadar kolesterol LDL 100-129 mg/dL sebesar 50 \%, responden dengan kadar LDL 130-159 $\mathrm{mg} / \mathrm{dL}$ yaitu sebesar 19,2 \%, responden dengan kadar kolesterol LDL 160-189 mg/dL yaitu sebesar 7,7 \%, sedangkan tidak didapatkan responden dengan kadar kolesterol LDL $\geq 190 \mathrm{mg} / \mathrm{dL}$ (Tabel 1).

Tabel 1. Distribusi responden berdasarkan kadar Kolesterol LDL dengan Kriteria NCEP ${ }^{14}$

\begin{tabular}{lcc}
\hline \multicolumn{1}{c}{$\begin{array}{c}\text { Kadar LDL } \\
\text { (mg/dL) }\end{array}$} & $\begin{array}{c}\text { Jumlah } \\
\text { responden(n) }\end{array}$ & $\begin{array}{c}\text { Persentase } \\
\text { (\%) }\end{array}$ \\
\hline $\begin{array}{l}\text { Normal/optimal } \\
(<100)\end{array}$ & 6 & 23,1 \\
$\begin{array}{l}\text { Mendekati } \\
\text { optimal } \\
(100-129)\end{array}$ & 13 & 0 \\
$\begin{array}{l}\text { Batas tinggi } \\
(130-159)\end{array}$ & 5 & 19,2 \\
$\begin{array}{l}\text { Tinggi } \\
(160-189)\end{array}$ & 2 & 7,7 \\
$\begin{array}{l}\text { Sangat tinggi } \\
(\geq 190)\end{array}$ & 0 & 0 \\
Jumlah & 26 & 100 \\
\hline
\end{tabular}

Jumlah responden dengan kadar kolesterol LDL yang mengalami peningkatan ( $\geq 100 \mathrm{mg} / \mathrm{dL}$ ) adalah 20 reponden dengan persentase sebesar 76,9 \% (Gambar 1).

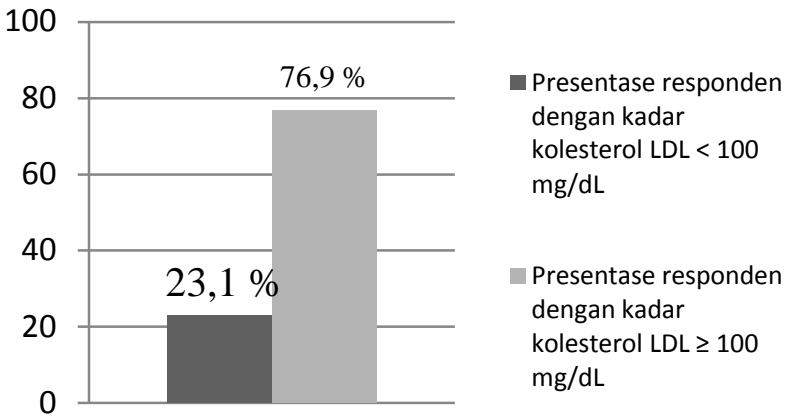

Gambar 1. Diagram distribusi responden berdasarkan kadar kolesterol LDL

\section{BAHASAN}

Hasil dari penelitian ini ditemukan 20 orang responden (76,9 \%) mengalami peningkatan kadar kolesterol LDL darah melebihi kadar normal atau optimal. Hal ini mendukung pernyataan dari Lipid Research Clinics Populations Studies Data Book, yang menyatakan bahwa remaja yang obes memiliki atherogenik lipid profil abnormal salah satunya peningkatan kolesterol low-density lipoprotein. $^{1}$

Hasil penelitian ini juga sejalan dengan penelitian yang dilakukan oleh Haryanto dkk pada tahun 2009. Pada penelitian dengan desain penelitian kasus control terhadap remaja dengan $\mathrm{IMT} \geq 23 \mathrm{~kg} / \mathrm{m}^{2}$ dengan IMT normal didapatkan hasil bahwa kadar kolesterol LDL darah pada berat badan berlebih lebih tinggi dibanding dengan berat badan normal. ${ }^{21}$ Berdasarkan data penelitianpenelitian diatas dapat dilihat bahwa peningkatan IMT dapat mempengaruhi kadar kolesterol LDL darah, meski peningkatannya tidak terlalu tinggi. Hal tersebut dapat disebabkan karena penimbunan lemak dijaringan adiposa menyebabkan peningkatan asam lemak yang merangsang produksi 
triasilgliserol, yang memungkinkan terjadi peningkatan sekresi dari VLDL yang nanti akan diurai menjadi IDL hingga LDL, sehingga dapat terjadi peningktan LDL dalam darah. $^{10,13}$

Peningkatan kadar kolesterol LDL darah pada usia muda dapat terjadi karena berbagai faktor, diantaranya adalah gaya hidup seperti kurangnya aktivitas fisik dan konsumsi makanan yang tinggi lemak atau karbohidrat. Aktifitas fisik berperan dalam menurunkan kadar kolesterol LDL darah karena dapat menyebabkan peningkatan enzim lipoprotein lipase. ${ }^{16}$ Hal ini sesuai dengan penelitian yang dilakukan oleh Oetji. Dari hasil penelitian tersebut didapati kadar kolesterol LDL darah pada mahasiswa yang melakukan olahraga tipe aerobik cukup lebih rendah dibanding yang melakukan aerobik tidak cukup. $^{17}$

Diet tinggi lemak maupun karbohidrat dapat meningkatkan total asupan energi dan meningkatkan kemungkinan terjadinya obesitas hingga peningkatan kadar kolesterol LDL darah. Dari penelitian Sargowo dkk didapatkan hasil uji yang bermakna antara asupan makanan dengankadar kolesterol LDL pada remaja. ${ }^{6}$

Selain itu, faktor keturunan juga ikut berpengaruh terhadap kadar kolesterol LDL. Mutasi pada gen reseptor LDL (R-LDL), dimana terjadi perubahan struktur maupun fungsi dari reseptor yang mengikat low density lipoprotein cholesterol (kolesterol LDL) plasma sehingga dapat mengakibatkan tingginya kadar kolesterol LDL dalam darah. $^{18}$

Dalam penelitian ini juga didapatkan sebanyak 6 orang responden memiliki kadar kolesterol LDL yang normal atau optimal. Hal ini sesuai dengan pendapat yang disampaikan oleh Setiawan yang menyatakan bahwa pada keadaan obesitas kadar kolesterol LDL darah dapat normal atau mengalami sedikit peningkatan. ${ }^{20}$ Hasil penelitian ini kemungkinan disebabkan karena proses metabolisme lemak yangmasih baik pada usia dewasa muda jika dibanding pada usia lanjut. $^{13,19}$

Kekurangan dari penelitian ini adalah jumlah sampel atau responden yang didapat dalam penelitian, tidak mencukupi sesuai dengan yang diharapkan. Jumlah responden yang diharapkan adalah 30 responden, namun pada saat penelitian ada beberapa mahasiswa yang telah bersedia menjadi responden berhalangan hadir pada saat pengambilan darah, sehingga responden yang berhasil didapatkan hanya berjumlah 26 orang responden.

\section{SIMPULAN}

Dari hasil penelitian tentang gambaran kadar kolesterol LDL darah mahasiswa angkatan 2011 Fakultas Kedokteran Universitas Sam Ratulangi dengan IMT $\geq 23 \mathrm{~kg} / \mathrm{m}^{2}$, dengan jumlah 26 responden didapatkan 20 responden mengalami peningkatan dan 6 responden normal.

\section{UCAPAN TERIMA KASIH}

Ditujukan kepada dr. Murniati Tiho, MKes dan dr. Youla Assa, MKes selaku penguji I dan II, serta dr. Aide Massie DAN DABK yang telah memberi masukan dan saran dalam penulisan serta kepada semua pihak yang secara langsung maupun tidak langsung telah memberikan ide atau gagasan dalam penulisan ini.

\section{DAFTAR PUSTAKA}

1. Rasional. Dislipidemia: Peningkatan Prevalensi dan Beban Kesehatan. Juni 2012. Available from URL: http://piolk.ubaya. ac.id/img/layanan/37_20120611114500.pdf

2. Prevalensi dan Faktor Associated dari Dislipidemia di Cina Populasi Dewasa. Plosone.10 maret 2011. Available from URL: http://www.plosone.org/article/info/Fjournal. pone.0017326

3. Gandha N. Hubungan Perilaku dengan prevalensi dislipidemia pada masyarakat kota 
Ternate tahun 2008. Jakarta: Fakultas Kedokteran Universitas Indonesia; 2009.

4. Martalina KT, Sulchan M. High fat intake and sport activity as risk factors of obesity hypertension in early adolescence. Journal Of Nutrition College. 2012;1:169-78.

5. Durstine L. Program olahraga: kolesterol tinggi. American College of sport Medicine. Soraya A K, editor. Jogyakarta: PT Citra Aji Parama, 2012;1-12.

6. Sargowo D, Andarini S. Pengaruh komposisi asupan makan terhadap komponen sindrom metabolik pada remaja. Jurnal Kardiologi Indonesia. 2011;32:14-23.

7. Kenali 4 Metode Efektif Penurunan Obesitas; Ala Samuel Oetoro. Sabtu, 5 Mei 2012. Available from URL: www.roche.co.id/ fmfiles/re7175008/indonesia/media/liputan.m edia/2012/kabarindo.

8. Hidayatulloh A, Nurhasanah A, Irawan E, Firdaus F, Isnaini F, Anggreini N, at all. Hubungan Faktor resiko obesitas dengan rasio lingkar pinggul Mahasiswa FKM UI. Jakarta: Universitas Indonesia. 2011. Available from URL: http://akgfkmui. files.wordpress.com/2012/03/jurnalfixed21.pdf

9. Mayes PA. Pengangkutan dan penyimpanan lipid, sintesis pengangkutan dan ekskresi kolesterol. Dalam : Murray RK, Granner DK, Mayes PA, Rodwell VW, editor. Biokima Harper (Edisi ke-25). Jakarta: EGC, 2003; p.254-81.

10. Marks DB, Marks AD, Smith CM. Biokimia kedokteran dasar : metabolisme kolesterol dan lipoprotein darah. Suyono J, Sadikin V, Mandera L, editor. Jakarta: EGC, 2000; p.513-23.

11. Schoen J.F,Cotran S.R. Pembuluh darah. Hartanto H, Dramaniah N, Wulandari N, editor. dalam: Buku Ajar Patologi Robins. (Edisi Ketujuh). Jakarta: 2007; p.369-78.

12. Sugondo S. Obesitas. Dalam: Sudoyo AW, Setiyohadi B, Alwi I, Simadibrata M, Setiati S, editor. Buku Ajar Ilmu Penyakit Dalam. Jilid III. Edisi 5. Jakarta: Pusat Penerbitan
Departemen Ilmu Penyakit Dalam Diponegoro, 2009: 1973-82.

13. Suyatna FD. Hipolipidemik. Dalam: Farmakologi dan Terapi (Edisi Kelima). Jakarta: Balai penerbit FKUI, 2007; p.374-85.

14. Adam J. Dislipidemia. Dalam : Sudoyo AW, Setiyohadi B, Alwi I, Simadibrata M, Setiati S, editor. Buku Ajar Ilmu Penyakit Dalam. Jilid III (Edisi Kelima). Jakarta: Pusat Penerbitan Departemen Ilmu Penyakit Dalam Diponegoro, 2009; p.1987.

15. Haryanto D, Madoyono B, Sjarif D R, Sastroasmoro $\mathbf{S}$. Hubungan Ketebalan Tunika Intima Media Arteri Carotis dengan Obesitas pada Remaja. Ilmu kesehatan anak. Padang: FK UNAND; 2009.

16. Stephanie L, Leni L, Wailanduw C, Rumawas M, Kidarsa VB. Hubungan Antara Pengeluaran Energi Harian Dengan Kadar Kolesterol Total pada Pasien Usia Minimal 30 Tahun. Jurnal kedokteran dan kesehan. 2010;16: 105-14.

17. Oetji TS. Perbandingan Kadar LDL, HDL, dan Rasio LDL/HDL pada Dewasa Muda yang Berolahraga Tipe Aerobik Cukupdan Tidak Cukup. Fakultas Kedokteran Universitas Kristen Maranatha; 2011.

18. Prawitasari T, Sastroasmoro S, Sjarif DR. Skrining Sistematik Terhadap Hiperkolesterolemia familial pada Anak Berdasarkan Kriteria MedPed, Simon Broome Register and Dutch Lipid Clinic. Sari Pediatri. 2011; 13:152-8.

19. Listiani L, Purbosari TY. Kadar kolesterol total pada usia 25-60 tahun. Bagian kimia analitik. Sidoarjo. Laboratorium RS Bahayangkara. Februari 2010. Available from: apps.um-surabaya.ac.id/jurnal/files/ disk1/1/umsurabaya-1912-linalistia-7-1kadarko-n.pdf.

20. Setiawan M. Peran resistensi insulin, adiponektin dan inflamasi pada kejadian dislipidemia aterogenik. Desember 2012. Available from URL: http://ejournal. umm.ac.id/index.php/sainmed/article/view/1 044(resistensi insulin). 